\title{
Katarzyna Szopa, Poetyka rozkwitania. Różnica ptciowa w filozofii Luce Irigaray, Wydawnictwo IBL PAN, seria Lupa Obscura, Warszawa, 2018, ss. 371
}

Ostatnia książka Katarzyny Szopy, będąca zmienioną wersją rozprawy doktorskiej obronionej w 2015 roku pod opieką Krystyny Kłosińskiej, poświęcona jest refleksji nad myślą Luce Irigaray — „Antygony współczesnej filozofii”. W ten sposób mówi o swojej naukowej niesubordynacji sama autorka Speculum, lecz tak patrzy również na swoją mentorkę Szopa, pisząc o tej, która „burzy ustanowiony porządek w imię własnych namiętności” (s. 15). Tytułowa „poetyka rozkwitania” jest owocem spotkania dwóch, bliskich sobie - w wymiarze intelektualnym, profesjonalnym, ale chyba też emocjonalnym - osobowości. Szopa — z wykształcenia literaturoznawczyni - ze znawstwem i pasją porządkuje, omawia i komentuje dorobek Irigaray, na który w sumie składa się ponad czterdzieści książek i setki artykułów, a zatem filozoficzny projekt, daleko wykraczający poza teksty znane polskiemu czytelnikowi z nielicznych tłumaczeń i komentarzy polskiej krytyki feministycznej (m.in. K. Kłosińskiej, A. Araszkiewicz, M. Baranowskiej, J. Bator, B. Smoleń czy M. Glosowitz). W efekcie otrzymujemy interdyscyplinarną rozprawę, która jest w polskiej humanistyce nie tylko najpełniejszym i najwierniejszym komentarzem myśli autorki Ciata-w-ciato z matka; to również eseistyczna propozycja, której konstrukcja wyrasta z performatywnego gestu pisania relacyjnego, dialogicznego, pełnego uważności i szacunku wobec myśli Irigaray. Można by w odniesieniu do strategii Szopy z powodzeniem powtórzyć słowa E. Grosz o francuskiej filozofce: jej „pisanie realizuje to, co obwieszcza” (s. 26). Zarówno zatem model myślowy autorki I Love to You, jak i strategię pisarską i lekturową Szopy określa tytułowa „poetyka rozkwitania”, odpowiadająca kierunkom roślinnego wzrostu, podporządkowanego swoim wewnętrznym, niepowtarzalnym rytmom; nakierowanym zatem nie tyle na ostateczny, jednowymiarowy, totalny efekt (rozkwit), ale śledzenie „pracy rozkwitania”, czyli ruchu znaczeń wibrujących w pisaniu tego, co pomiędzy, co jest tego pisania „oddechem”. Szopa tak właśnie „gości” w swojej książce 
myśli i słowa Irigaray, kontemplując je w różnicy, odsłaniając tym samym złożone związki między poetyckością a materialnością. Etymologiczne podobieństwo greckich pojęć poiein i phuein, wskazujących na tworzenie i wzrastanie, odsyła do podstaw filozofii Irigariańskiej, w której relacja między sztuką tworzenia a sztuką wzrastania skłaniania ku byciu, jest relacją nierozerwalną i fundamentalnie ontologiczną. „[S]ztuka poetycka — przekonuje filozofka winna być dążeniem do ocalania i działania na rzecz phuein, czyli stawania się, które nie oddziela formy od materii. Wówczas forma nie rości sobie prawa do dominowania nad materią, lecz służy jej rozkwitaniu i wzrastaniu” (s. 28). Wybór „poetyki rozkwitania” pozwala Szopie wydobyć zróżnicowane i złożone konteksty pism filozofki, dla których w ewolucyjnym rozwoju myśli, kluczowe pozostają pojęcia: różnicy płciowej (sexuate difference), tożsamości relacyjnej i, na różnych poziomach, materialności języka i świata.

A zatem idąc tropem tej roślinnej poetyki, Szopa ujmuje swój tekst w trzy opowieści (uporządkowane dodatkowo, jakże słusznie, w mniejsze podrozdziały) o znamiennych tytułach Kietkowanie, Wzrastanie i Rozkwitanie. Pierwsza ma charakter rewizyjny, odsyła bowiem do „korzeni” Irigariańskiej myśli. Wymaga zatem odpowiedzi na pytanie, jak i gdzie w feministycznej historiografii usytuować Irigaray (rozdz. I), czy wolno nam nazywać ją esencjalistką lub dekonstrukcjonistką (rozdz. II), jak określenia te wpłynęły na zatracenie wyjątkowości i specyfiki jej filozofii wśród głównonurtowych narracji zachodnich feminizmów i jak rozumieć tę wyjątkowość w perspektywie nowomaterialistycznej (rozdz. III). Szopa przekonująco pokazuje, że właśnie materializm jest w myśli Irigaray innowacyjną perspektywą, którą mylnie utożsamiano w esencjalizmem. W tym ujęciu nowy materializm nie jest wyłącznie formacją młodszego pokolenia - Irigaray staje w tym dyskursie obok takich badaczek jak K. Barad, E. Grosz czy N. Tuana, które od lat 90. XX wieku domagają się nowych onto-epistemologii feministycznych, a tym samym przedefiniowania pojęcia podmiotowości, różnicy i ciała. Dla Irigaray podstawową kwestią jest tytułowa różnica płciowa, która w zachodniej kulturze uległa neutralizacji, została przekształcona w linearną, fallogocentryczną logikę Tego Samego, wykluczającą to co kobiece ze wszystkich porządków kultury, także ze sfery społecznej i politycznej. Dlatego przyjęcie w dyskursie pozycji podmiotowej tożsame jest dla niej z „mówieniem jako kobieta” (parler femme), z wprowadzaniem alternatywnych przedstawień kobiecego ciała (np. figura dwóch warg czy ekonomia łożyska) i podmiotowości, zawsze usytuowanej, ucieleśnionej, funkcjonującej poza opozycjami, a zwracającej się w kierunku różnic, otwartej na inność w aspekcie relacyjnym.

Druga część rozprawy Szopy pt. Wzrastanie (s. 151-193) poświęcona jest w całości śledzeniu zmian, jakim podlega w filozofii Irigaray pojęcie różnicy płciowej. Autorka wychodzi od opisu rekonfiguracji tradycji freudowsko-lacanowskiej (spekulatywność i spekularność jako praca myśli i praca lustra), które prowadzą w stronę zasiedlenia przestrzeni kultury symboliką znoszącą iluzję symetrii Tego Samego. Pokazuje tym samym drogę, jaką przechodzi filozofka, inicjująca nowe formy reprezentacji wymykające się ekonomii opartej na odzwierciedlaniu bądź powielaniu. W zamian proponuje poetykę mimetycznego i inwersyjnego przedrzeźniania czy też metonimicznego przesunięcia. Anagenatyczna (od gr. anagennáo - znów, na nowo rodzę), zanurzona w materialności kobiecej poetyka narodzin jest dla niej zobowiązaniem do ciągłego stawania się innym innego, stawania się innością; oznacza „odradzanie się i zdolność do twórczego przekształcania cielesnych form i ich kulturowych reprezentacji" (s. 174). 
Jednym z najważniejszych wątków tego rozdziału jest problematyka etyki różnicy płciowej. Autorka doprecyzowuje tytułowe pojęcie, podkreślając, że błędne jest utożsamianie go z różnicą seksualną (wagina kontra penis) czy różnicą na poziomie płci kulturowej, bo to prowadzi do nieporozumień interpretacyjnych i oskarżeń filozofki o homofobię, esencjalistyczny redukcjonizm czy lekceważenie problematyki różnic klasowych, rasowych, kulturowych oraz etnicznych. Irigaray zamienia francuski przymiotnik sexuel(le) na sexué(e), a angielskie sexual na neologizm sexuate, by podkreślić, że „różnica płciowa” (sexuate difference) jest dla niej nadrzędna i oznacza szczególny sposób wchodzenia w relacje z innym(i) i ze światem (s. 177). Dlatego należy raczej postrzegać ją jako proces czy efekt wielowymiarowych relacji - cielesnych, społecznych, językowych, estetycznych, erotycznych czy politycznych, i pytać nie o to „czy”, ale „jak” ta różnica istnieje. Oznacza to, że dla autorki Éthique de la différence sexuelle (1984) „różnica płciowa to przede wszystkim różnica na poziomie tożsamości relacyjnej” (s. 177) stojącej w opozycji zarówno wobec dyscyplinującej ciała polityki tożsamości, procesów wkluczania i wykluczania w imię uporządkowanej homogenicznej totalności, jak i wszelkich postaw indywidualistycznych i egocentrycznych. Jak podkreśla Szopa, „[r]óżnica płciowa wypracowana jest więc w drodze etycznych rozważań nad relacyjnością człowieka i stanowi parametr ludzkiej egzystencji, który wskrzesza pamięć o tym, że nie żyjemy na świecie ani sami, ani sami dla siebie” (s. 178). Z przyjemnością śledzi się wielopoziomowy wywód Autorki, która, idąc śladem krytycznych komentarzy prac filozofki, wydobywa i torpeduje wszelkie nieścisłości, niedoczytania, pozorną aporetyczność jej myślenia. Z wielką erudycją pokazuje przy tym, jak różnica płciowa stopniowo wyłania się jako podstawa Irigariańskiego projektu ontologii relacji, w którym pojęcie obecności zastąpione zostaje pojęciem relacyjności pomiędzy dwoma upłciowionymi podmiotami (heteropłciowe to nie to samo co heteronormatywne); „bycie” jest zawsze „byciem-z”, a „stawanie się” — „stawaniem-się-z-innym”. Ta ewolucja myśli dotyczy także poziomu języka, a najlepszym przykładem zmiany strategii pisarskiej pod wpływem różnicy płciowej jest przejście od wspomnianej wcześniej metaforyzacji/metonizmiacji języka do figury diafory, uwzględniając pracę różnicy wewnątrz znaczenia.

W ostatniej części książki zatytułowanej Rozkwitanie (s. 195-341) znajdujemy analizę obszarów tematycznych, takich jak miłość, gościnność i roślinność, które służą zobrazowaniu sposobu, w jaki dochodzi do zrekonceptualizowania różnicy płciowej i przeniesienia jej poza ramy dyskursu antropocentrycznego. Najpierw Autorka opisuje, w jaki sposób Irigaray obnaża fantazmatyczne podstawy kultury Zachodu, a mianowicie wyłoniony w wyniku „pierwotnego matkobójstwa” apolliński i dionizyjski model nieprzepracowania relacji z początkiem; pierwszy dotyczy oderwania od źródła i ciągłej za nim tęsknoty, drugi kształtuje imaginarium kulturowe związane z powrotem do źródeł jako przestrzenią pierwotnego niezróżnicowania. Irigaray, idąc za logiką różnicy płciowej, proponuje myślenie nie tyle o źródłach, które jej zdaniem nigdy nie są pojedyncze, ile o początkach poza imperatywem matczyności i ojcostwa. Filozofka wprowadza trzecią siłę, Erosa — rozumianego jako pragnienie, które jest rodzajem energii relacyjnej, siłą skłaniająca nas do wyjścia poza nasz świat ku innemu. W tym projekcie podmiotowego spotkania kluczowe (na poziomie mikro- i makrorelacji) są pojęcia samopobudzenia (self-affection), samoutulenia, samopoznania, podkreślające, że wejście kobiety w relacje z innym poprzedzić musi cielesna i duchowa relacja „bycia-w-sobie” i „-ze-sobą”; ta dyspozycja zakłada podmiotową integralność i nienaruszalność, a jednocześnie nienarcystyczną miłość do siebie, która - jak słusznie zauważa Szopa - ma potencjał przełamania 
kulturowych wzorców opieki, opartych na idei naturalnej skłonności poświęcania się / miłości kobiet do/dla innych. Co więcej, by przekształcić relacje między płciami zgodnie z ekonomią Erosa, należy dokonać także przeformułowania w języku, który jest sposobem naszego bycia i budowania relacji w świecie.

W kolejnych podrozdziałach Autorka problematyzuje współbieżność gościnności i różnicy płciowej w kontekście kultury gościnności J. Derridy i niematerialnej gościnności E. Levinasa. Interesująca jest w tym projekcie Irigariańska interpretacja historii zwiastowania Marii, wykraczająca zarówno poza dominującą w tradycji gościnności ekonomię wymiany, jak i ekonomię daru, tożsamego w kulturze z macierzyństwem. Efektem tego przeformułowania miałaby być, oparta na etyce wzajemnej gościnności, rekonfiguracja pojęcia wspólnoty i wszelkich zinstytucjonalizowanych form organizacji społeczeństw, m.in. rodziny, ale także wspólnot kulturowych, narodowych czy religijnych w wymiarze globalnym. Etyka ta „wymaga uznania i poszanowania przestrzeni należącej do innej lub innego oraz otwarcia przestrzeni między dwoma nieredukowalnymi względem siebie podmiotami. Możliwe jest to tylko dzięki pielęgnowaniu kultury różnic, a nie kultury podobieństw i różnorodności” (s. 276).

Najwłaściwszym domknięciem „pracy rozkwitania” jest omówienie koncepcji Irigaray w planie ekokrytycznym. Odwołując się do intelektualnego herbarium Irigaray, Szopa na różnych poziomach tłumaczy, dlaczego paradygmat myślowy oparty na modelu roślinnego wzrostu i rozkwitania oddaje w myśli filozofki kondycję ludzkiej podmiotowości. Przemyślenie różnicy płciowej wiąże się z bezwzględną koniecznością przemyślenia tego, co ludzkie, ale też tego, co roślinne. Ten kierunek myślenia bazujący na przeformułowaniu tradycyjnej ikonografii (drzewa, kwiatu, kłącza) pokazuje, jak Irigaray w roślinnej egzystencji odkrywa potencjał życia, który wymyka się jakimkolwiek zasadom logiki formalnej. Relacyjny wymiar egzystencji roślin rosnących i zakorzenionych w materii, powietrze jako przestrzeń mediacji, przestrzeń „bycia razem”, wreszcie lekcja oddychania, jakiej rośliny udzielają człowiekowi - wszystko to prowadzi wg Irigaray do wyznaczenia nowych dróg w stawaniu-się-człowiekiem. Myślenie o różnicy płciowej jest w tym ujęciu myśleniem o wyraźnie postantropocentrycznych uwikłaniach, w którym kształtowanie się człowieczeństwa jako bycie-w-świecie jest zawsze nawiązywaniem więzi z innym(i), niezależnie od tego, czy są to ludzie, zwierzęta czy rośliny, przy zachowaniu własnej integralności i poszanowaniu przynależności oraz w procesie rozkwitania, który jest możliwy dzięki wymianie energii między dwoma różnymi bytami.

Książka Szopy nie posiada tradycyjnego zakończenia - i słusznie, bo trudno byłoby takie sformułować. Zamiast tego znajdujemy inspirujący podrozdział poświęcony roli oddechu w egzystencji człowieka i świata, zamykający refleksję na temat różnicy płciowej. Oddech, pierwszy gest życia wszystkich organizmów, gest nie tylko biologiczny, ale także duchowy („pierwotnym znaczeniem słowa «dusza», było słowo «oddech» — przypomina filozofka) staje się figurą fundamentalnego zapomnienia, jakie owładnęło zachodnią kulturę i tradycję; zapomnienia związanego z różnorodnością wpisaną w życie (s. 340).

Spotkanie z książką Szopy nie zamyka „pracy rozkwitania”. Wobec tego tekstu nie sposób bowiem pozostać obojętnym. Nad jego lekturą nadbudowują się pytania o fundamentalne problemy naszej cywilizacji, pytania o to, czym jest życie, kim jesteśmy jako ludzie, jakie są nasze relacje ze światem, jaka jest etyczna wartość naszego współ-egzystowania, dlaczego godzimy się / współtworzymy(?) kulturę wykluczenia zgodnie z logiką Tego Samego, dlaczego zapomnieliśmy o bioróżnorodności świata?... 
Katarzyna Szopa, pozostając z dorobkiem Irigaray w relacji pełnej wrażliwości i uznania, próbuje otworzyć czytelnika na myślenie w kategoriach różnicy płciowej, która w ujęciu filozofki przestaje być funkcją władzy, stając się operacyjnym pojęciem o silnym potencjale odnowy znaczeń oraz ważnej sile sprawczej i emancypacyjnej. Składają się nią takie kategorie jak: współ-bycie, relacja, gościnność, wzajemność (nie wymiana), miłość (zamiast podporządkowania), uznanie (nie wykluczenie), dotyk — bliskość (w miejsce spojrzenia — zawłaszczenia), materia (nie idea), ruch. Poetyka rozkwitania to bez wątpienia potrzebna i ważna pozycja w dorobku polskiej humanistyki.

AgnieszKa GaWron

(iD https://orcid.org/0000-0001-8891-6563 